\title{
CHANGES IN EMPLOYMENT IN THE PRIMARY SECTOR ACROSS PREDOMINANTLY RURAL POLISH SUBREGIONS
}

\author{
Nina Drejerska ${ }^{1,} \mathrm{PhD}$ \\ ${ }^{1}$ Warsaw University of Life Sciences
}

\begin{abstract}
Research on evolution of the economic structure is an important part of the state-of-the art in economics. As basic indices indicating the significance of agricultural sector have been decreasing, it is important to study a role of the primary sector for employment. This is especially reasonable for rural areas. The main aim of the paper is to investigate transformation of employment structure across predominantly rural Polish subregions (NUTS 3), particularly, changes in employment in the primary sector. Data of the Central Statistical Office of Poland on the sectoral structure of employment in predominantly rural Polish subregions in 2010 and 2016 were applied for the shiftshare analysis.

All predominantly rural subregions were characterized by relatively high rates of employment in the primary sector, both at the beginning as well as at the end of the investigated period. However, the primary and secondary sectors were characterized by negative values describing the industry-mix effect (IM), which indicates negative impact of subregional specialization - employment in these sectors grow slower comparing to the national average. There are only 10 (out of 31 ) subregions characterized by positive values of the regional shift effects (RS). Alongside with a negative industry-mix effect, it indicates that the primary sector was a poor performer nationally as a sector of employment but performance was better in these subregions than at the national level. Negative values both for IM and RS (21 subregions) indicate that the primary sector was a poor performer nationally as a sector of employment and even poorer in these subregions than at the national level.
\end{abstract}

Key words: primary sector, employment structure, predominantly rural region, shift-share analysis.

JEL code: C43, J21, J43, R11

\section{Introduction}

The main aim of the paper is to investigate transformation of employment structure across predominantly rural Polish subregions (NUTS3), particularly changes in employment in the primary sector. Research on evolution of economic structure, one of the major research area of economists in the post-war period, indicates a necessity to include sectoral specificity in the research programme of development economics referring to the works of Simon Kuznets. This Nobel prize winner in economic sciences states that economic sectors are characterized by different specificity of products, production and innovation processes, but also of working and living conditions of engaged persons (Grodzicki M., 2014).

A review of the state-of-the-art proves that some researchers study a general sectoral structure of employment (Hedlund M., Lundholm E., 2015), some focus on particular sectors (Klembowska D., 2012). It is not surprising that employment in the primary sector is most important in rural and least important in urban regions (European Commission, 2017); thus, this study focuses on employment in agriculture, forestry and fishing. Although it may be noticed, year by year, that basic indices describing the significance of agriculture for the world economy have been decreasing (Chrzanowska M., 2017), agriculture is still a very important sector of regional economies and as a result regional as well as local labour markets. However, the situation is diversified across Polish subregions (Drejerska N., Chrzanowska M., 2017). There are some predominantly rural subregions where the primary sector develops more dynamically than it is characterized by tendencies in changes of national accounts. In such a situation, a shift-share analysis can be useful to analyse differences between subregional and national growth rates (Markusen A.R., Noponen H., Driessen K., 1991). In other words, this method permits comparison of growth in a specific sector of the economy in different regions. It was clearly formulated by Dunn (Dunn E. S., 1960), one of researchers who introduced the shift-share analysis to economic and spatial investigations. 
The classical shift-share analysis assumes a three-component model of regional change, incorporating national share (NS), industry mix (IM), and regional shift (RS). Thus (Stimson R. J., Stough R. R., Roberts B. H., 2006):

$$
\begin{gathered}
\Delta \mathrm{e}_{i} \equiv \mathrm{e}_{i, t}-\mathrm{e}_{i, t-1} \equiv \mathrm{NS}_{i}+\mathrm{IM} \mathrm{M}_{i}+\mathrm{RS}_{i} \\
\mathrm{NS} \mathrm{S}_{i} \equiv \mathrm{e}_{i, t-1}\left(\mathrm{E}_{t} / \mathrm{E}_{t-1}-1\right) \\
\mathrm{IM}_{i} \equiv \mathrm{e}_{i, t-1}\left(\mathrm{E}_{i, t} / \mathrm{E}_{i, t-1}-\mathrm{E}_{t} / \mathrm{E}_{t-1}\right) \\
\mathrm{RS}_{i} \equiv \mathrm{e}_{i, t-1}\left(\mathrm{e}_{i, t} / \mathrm{e}_{i, t-1}-\mathrm{E}_{t} / \mathrm{E}_{t-1}\right) \\
\left.\mathrm{e}_{i, t} \equiv \mathrm{e}_{i, t} t-1+\left(\mathrm{NS}_{i}+\mathrm{I} \mathrm{M}_{i}+\mathrm{RS}\right)_{i}\right)
\end{gathered}
$$

Where:

$\mathrm{e}_{i}$ and $\mathrm{E}_{i}$ respectively are regional and national employment in industry $\mathrm{i}_{\text {; }}$

e and $\mathrm{E}$ respectively are regional and national total employment in all industries;

$\mathrm{t}-1$ is the initial period and $\mathrm{t}$ the end period of the analysis.

Giannakis and Bruggeman (Giannakis E., Bruggeman A., 2017) reviewed interpretation of these three components, which for the subregional level of this analysis can be summarized as follows:

1) a national growth effect (NS) measures the change in the subregional employment that would have occurred if the subregional employment had grown at the same rate as the national; it portrays the share of subregional job growth attributable to the growth of the national economy;

2) an industry-mix effect (IM) attributes changes in employment to changes in the industrial composition of the subregion; it reflects the positive or negative impact of subregional specialization in sectors that are slow or fast growing relative to the national average, respectively; IM > 0 can be interpreted as an indicator of a diverse set of sectors, while IM $<0$ can be interpreted as an indicator of a specialized economy;

3) a regional shift effect (RS) measures the change in subregional employment attributable to subregional advantages and/or competitiveness; it may result from natural endowments, the entrepreneurial ability of the subregion and other comparative advantages or disadvantages.

For the purposes of this paper, the classical shift-share analysis was applied. However, it is worth mentioning that this method has some further developments, for example in a form of the dynamic shiftshare analysis (Barff R. A., Knight III P. L., 1988). Nazara and Hewings (Nazara S., Hewings G.J.D., 2004) implemented a new shift-share model assuming the existence of spatial dependence between the geographic units by means of the definition of a spatial weight matrix.

Previous research with application of the shift-share method often focus on the regional level (NUTS 2) (Sobczak E., 2015; Zemkova K., Bartova L., 2013). In such a situation, investigating subregions enables identification of those smaller areas which have been slowing down or accelerating the economic performance of larger units - NUTS 2 (Oguz S., Knight J., 2010). In other words research on subregions allow to be more precise in identification of economic development or slowdown across the space. This is a logical consequence of a hierarchical structure of the territorial division - regional development takes place in a national framework and depends in part on forces operating at the national level (Dunn E. S., 1960), but local development is not autonomic development in a smaller scale - it reflects bottom-up regional development (Rakowska J., 2016). Therefore, the primary objective of the research is to investigate structural changes on a possibly low level of a territorial division. That is why the European Union (EU) typology of NUTS3 regions divided into predominantly rural, intermediate, and predominantly urban regions (Eurostat, Urban-rural Typology) was applied for the purposes of this study (Fig. 1). In Poland, there were 15 predominantly urban regions, 26 intermediate regions and 31 predominantly rural regions (investigated in this paper) according to this methodology in 2016. 
Traditional division (Kenessey Z., 1987), which is still used by contemporary research (Hueske AK., Guenther E., 2015), into a primary, secondary, tertiary and quaternary sector was applied.

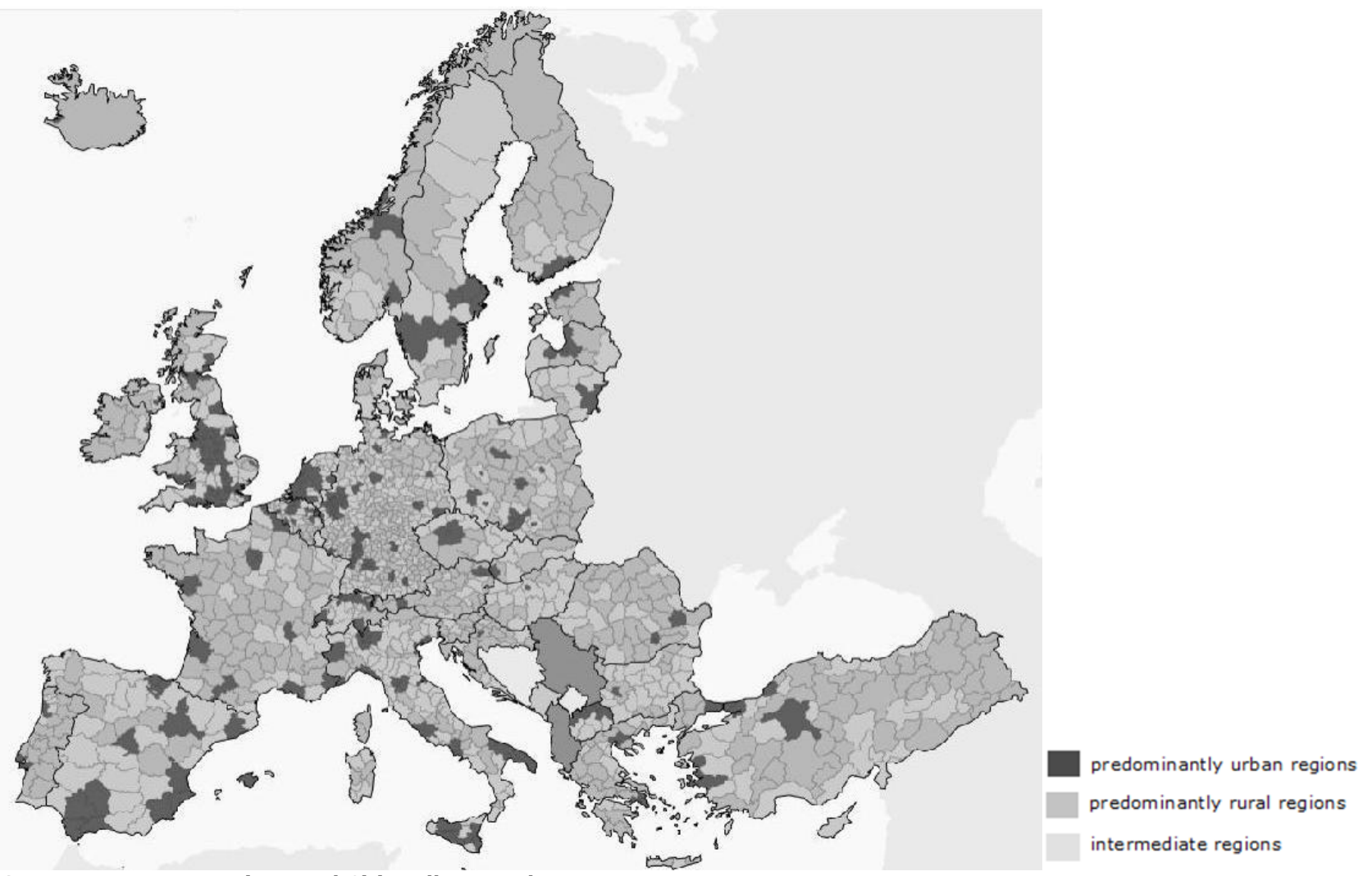

Source: Eurostat, Regions and Cities Illustrated

Fig. 1. Urban-rural typology by NUTS3 regions

According to the classification of the Central Statistical Office of Poland, a provider of data on a number of employed persons within the Local Data Bank, this traditional division looks as follows:

- primary sector - agriculture, forestry, fishing; secondary sector - industry, construction;

- tertiary sector - trade; repair of motor vehicles; transportation and storage; accommodation and catering; information and communication;

- quaternary sector - financial and insurance activities; real estate activities and other services: professional, scientific and technical activities, administrative and support service activities, public administration and defence; compulsory social security, education, human health and social work activities, arts, entertainment and recreation other service activities.

\section{Research results and discussion}

It is obvious that the most significant scale of employment in the primary sector occurs on rural areas. It was the most important sector of employment accounted for about one third of employment in the analysed period (Tab. 1).

Sectoral employment structure in Poland according the urban-rural typology (\%)

\begin{tabular}{|l|l|r|r|r|r|r|r|r|r|}
\hline \multirow{2}{*}{ No } & \multirow{2}{*}{ Type } & \multicolumn{2}{|c|}{ Primary } & \multicolumn{2}{c|}{ Secondary } & \multicolumn{2}{c|}{ Tertiary } & \multicolumn{2}{c|}{ Quaternary } \\
\cline { 3 - 10 } & & $\mathbf{2 0 1 0}$ & $\mathbf{2 0 1 6}$ & $\mathbf{2 0 1 0}$ & $\mathbf{2 0 1 6}$ & $\mathbf{2 0 1 0}$ & $\mathbf{2 0 1 6}$ & $\mathbf{2 0 1 0}$ & $\mathbf{2 0 1 6}$ \\
\hline 1. & predominantly urban & 2.54 & 2.32 & 26.37 & 23.59 & 29.88 & 30.25 & 41.21 & 43.84 \\
\hline 2. & intermediate & 15.89 & 14.58 & 30.40 & 30.06 & 25.00 & 25.38 & 28.71 & 29.97 \\
\hline 3. & predominantly rural & 32.80 & 31.08 & 25.21 & 25.53 & 18.78 & 19.30 & 23.21 & 24.09 \\
\hline
\end{tabular}

Source: author's calculations based on data of the Central Statistical Office of Poland 
As mentioned in the introduction, the primary sector plays a different role in regional and subregional economies across the country. Undoubtedly, agriculture, forestry and fishing are important for employment in the south-eastern part of Poland (Fig. 2). All predominantly rural subregions located there can be characterized by relatively high rates of employment in the primary sector, both at the beginning as well as at the end of the investigated period. Similar results on regional and subregional differentiation in Poland can be confirmed by other research (Drejerska N., 2015; Pomianek I., 2016). This situation can result from advantageous conditions for agricultural activities there, a traditionally significant role played by this sector in this part of Poland as well as agricultural land fragmentation and agrarian overpopulation in some of these areas (Musial W., Wojewodzic T., 2015).

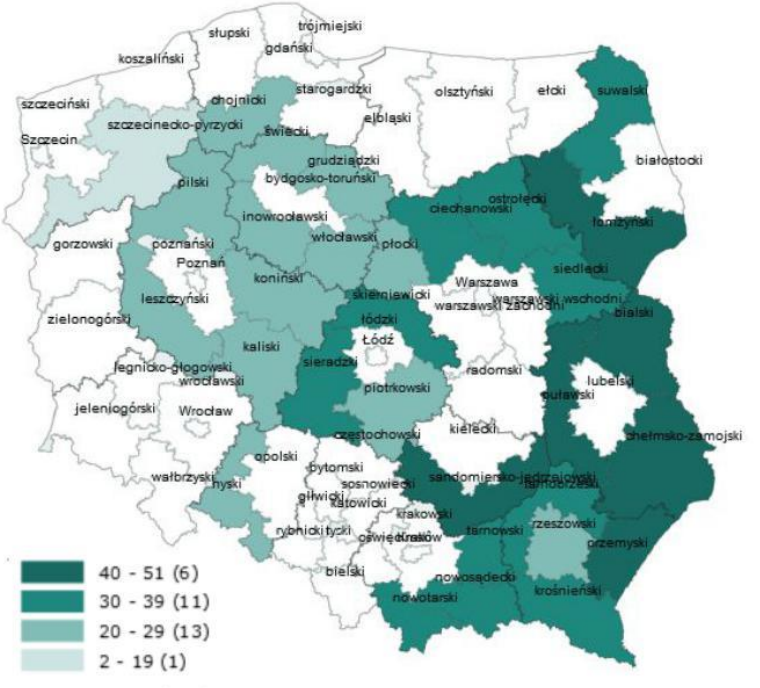

2010

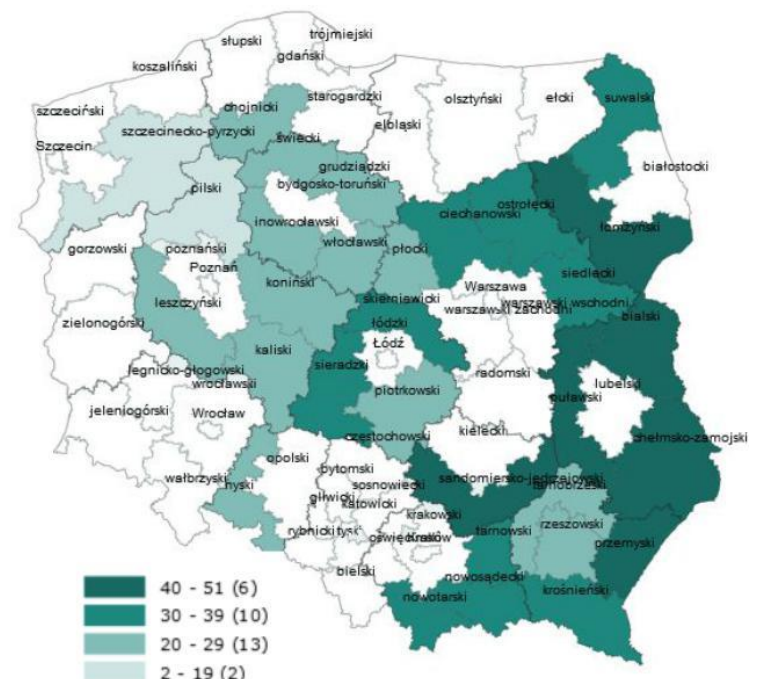

2016

Source: author's calculations based on data of the Central Statistical Office of Poland

Fig. 2. Employment in the primary sector on predominantly rural subregions ( \%)

Table 2 presents the results of the classical shift-share analysis for the employment structure in Polish predominantly rural subregions for the years 2016 and 2010. A general increasing tendency of employment can be identified, which is proved by the value of the national growth effect: $8.61 \%$. This component describes the change that would be expected due to the fact that a subregion is part of a dynamic national economy (Oguz S., Knight J., 2010). Individual industry-mix effects for particular sectors are quite diversified, starting from the lowest $-8.19 \%$ for the primary sector and ending with the highest positive value $(5.98 \%)$ for the quaternary sector. The primary and secondary sectors are characterized by negative values, which indicates negative impact of subregional specialization - these sectors grow slower comparing to the national average. It is not surprising as results of regional development studies suggest that employment in agriculture and other land-based industries has a decreasing tendency, so the economic fortunes of rural areas have come to depend upon a much wider range of drivers than the economic fortunes of the primary sector (Ward N., Brown D.L., 2009). 


\section{Results of shift-share analysis with regard to effects of structural employment changes (\%)}

\begin{tabular}{|l|l|l|c|}
\hline No & \multicolumn{2}{|c|}{ Effects of structural employment changes } & $\%$ \\
\hline \multirow{2}{*}{ 1. } & national growth effect (growth rate of employment in Poland) & 8.61 \\
\hline \multirow{3}{*}{ 2. } & \multirow{3}{*}{} & industry-mix effect & -8.19 \\
\cline { 3 - 4 } & & primary sector & -3.57 \\
\cline { 3 - 4 } & & tertiary sector & 2.22 \\
\cline { 3 - 4 } & & quaternary sector & 5.98 \\
\hline
\end{tabular}

Source: author's calculations.

Investigation of regional shift effects is the last part of the shift-share analysis. RS values for the primary sector in predominantly rural areas are presented on the Figure 3. Regional shift effects for 21 (out of 31) subregions are negative, which can be interpreted as employment specialization of these areas in the primary sector. Negative values both for IM and RS indicate that the primary sector was a poor performer nationally as a sector of employment and even poorer in these subregions than at the national level.

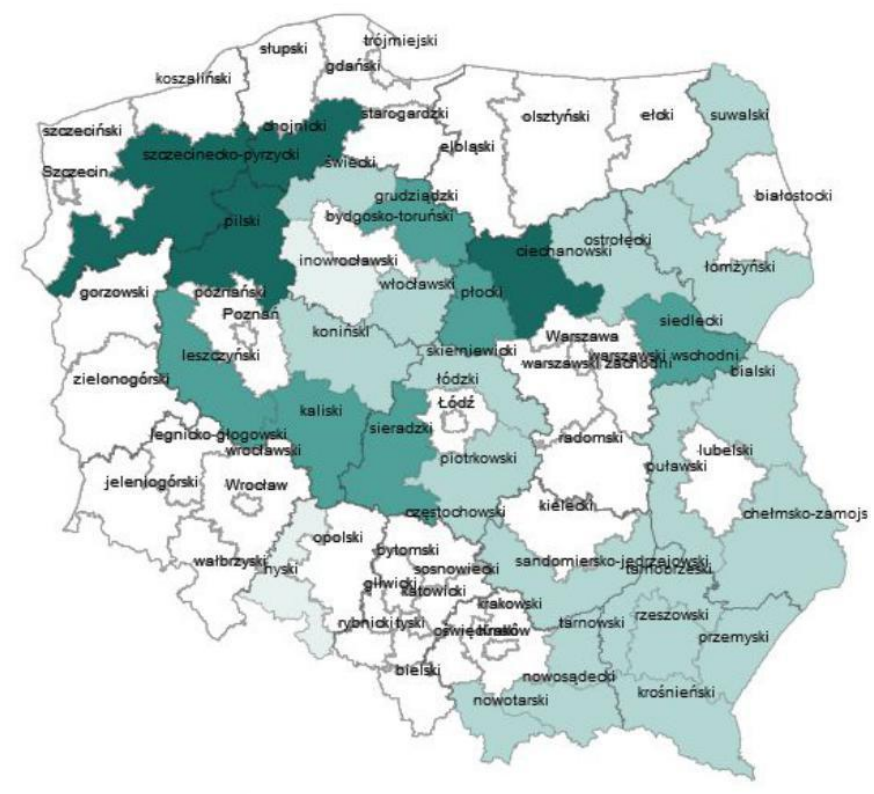

Source: author's calculations

Fig. 3. Regional shift effect for employment in the primary sector on predominantly rural subregions (\%)

There are only 10 subregions characterized by positive values of the regional shift effects. Alongside with the negative industry-mix effect, it indicates that the primary sector was a poor performer nationally as a sector of employment but better in these subregions than at the national level (Karlsson Ch., Andersson M., Norman T., 2015). Undoubtedly, this research should be develop in order to include for example an issues of labour productivity in agriculture, which in Polish farming was much lower in comparison with other countries as well as other links of the food sector and the national economy (Golebiewski J., 2013).

\section{Conclusions}

Although the primary sector can be characterized by a decreasing tendency, it is still important in the sectoral structure of employment across predominantly rural subregions in Poland. The results of the shift-share analysis allows for the following conclusions: 
1) a general increasing tendency of employment can be identified, which is proved by the value of the national growth effect;

2) the primary and secondary sectors are characterized by negative values of the industry-mix effect which means that their employment grows slower comparing to the national average;

3) regional shift effects for 21 (out of 31 ) subregions are negative, which can be interpreted as employment specialization of these areas in the primary sector and alongsides with the negative industry-mix effect it means that the primary sector is a poor performer nationally as a sector of employment and even poorer in these subregions than at the national level.

However, some further analysis should be carried out in order to present a coherent view of the sectoral structure of subregional economies across predominantly rural subregions as for example a lack of the dynamic increase in employment alongside with increase in the value added generated by the primary sector can be interpreted as a trend of increasing efficiency. Further studies can be also developed with use of the dynamic or spatial shift-share method.

\section{Bibliography}

1. Barff, R. A., Knight III, P. L. (1988). Dynamic Shift-Share Analysis. Growth and Change, 19, pp. 1-10.

2. Chrzanowska, M. (2017). Multidimensional Comparative Analysis of the Polish Agri-food Sector in Regard to Other EU Countries in the Years 2004-2014. Proceedings of the 2017 International Conference Economic Science for Rural Development, No 44 Jelgava, LLU ESAF, 27-28 April 2017, pp. 323-329

3. Drejerska, N, Chrzanowska, M. (2017). Sectoral Employment Diversification in Rural Areas Across Polish Subregions. Roczniki Naukowe Ekonomii Rolnictwa i Rozwoju Obszarow Wiejskich 2017, vol. 104, nr 4, pp. 28-36.

4. Drejerska N. (2015): Spatial Patterns on the Labour Market on Rural Areas in Poland. Proceedings of the International Scientific Conference: Rural Development 2015, 5 s.

5. Dunn, E. S. (1960). A Statistical and Analytical Technique for Regional Analysis. Papers in Regional Science, 6, pp. 97- 112 .

6. European Commission (2017). CAP Context Indicators 2014-2020. 2017 Update, p. 47.

7. Eurostat, Regions and Cities Illustrated, http://ec.europa.eu/eurostat/cache/RCI/\#?vis=urbanrural.urb_typology\&lang=en. Access: 10.01.2018

8. Eurostat, Urban-rural Typology, http://ec.europa.eu/eurostat/statistics-explained/index.php/Urbanrural_typology. Access: 10.01.2018

9. Giannakis, E., and Bruggeman, A. (2017). Economic Crisis and Regional Resilience: Evidence from Greece. Papers in Regional Science, 96, pp. 451-476.

10. Golebiewski, J. (2013) Changes in Competition Trends and Labour Productivity in the Marketing Chain of Foodstuffs. Economic Science for Rural Development Conference Proceedings. 2013, Issue 32, pp. 178-183.

11. Grodzicki, M. (2014), Structural Similarities of the Economies of the European Union. Equilibrium. Quarterly Journal of Economics and Economic Policy, Volume 9, Issue 1, pp. 93-117,

12. Hedlund, M., Lundholm, E., (2015). Restructuring of Rural Sweden - Employment Transition and Outmigration of Three Cohorts Born 1945-1980. Journal of Rural Studies 42, p. 124.

13. Hueske, AK. \& Guenther, E. (2015). What Hampers Innovation? External Stakeholders, the Organization, Groups and Individuals: a Systematic Review of Empirical Barrier Research. Manag Rev Q (2015) 65, pp. 113-148.

14. Karlsson, Ch., Andersson, M., Norman, T. (2015). Handbook of Research Methods and Applications in Economic Geography. Edward Elgar Publishing, p. 88.

15. Kenessey, Z (1987). The Primary, Secondary, Tertiary and Quaternary Sectors of the Economy. Rev Income Wealth 33(4), pp. 359-385.

16. Klembowska, D. (2012). Determinants of Employment in Industrial Enterprises in Poland. Electronic Journal of Polish Agricultural Universities. Economics 2012, Vol. 15, Issue 2, 6 p.

17. Markusen, A.R., Noponen, H., Driessen, K. (1991). International Trade, Productivity, and U.S. Regional Job Growth: A Shift-Share Interpretation. International Regional Science Review Volume 14, Issue 1, pp. 15-39.

18. Musial, W., Wojewodzic, T. (2015). Zroznicowanie regionalne rolnictwa rodzinnego i sytuacja produkcyjnoekonomiczna rodzinnych gospodarstw rolnych funkcjonujacych w roznej strukturze agrarnej (Regional Diversification of Family Farming and Production and Economic Situation of Family Farms Operating with Different Agrarian Structure) Podstawka M. (red) Ekonomiczne i prawne mechanizmy wspierania i ochrony rolnictwa rodzinnego (Economic and Legal Mechanisms of Support and Protection of Family Farming). Fundacja Programow Pomocy dla Rolnictwa FAPA, Warszawa, pp. 26-45

19. Nazara, S., Hewings, G.J.D. (2004). Spatial Structure and Taxonomy of Decomposition in Shift-Share Analysis. Growth and Change, Wiley Blackwell, vol. 35(4): 476-490.

20. Oguz, S. \& Knight, J. (2010) Regional Economic Indicators: with a Focus on Sub-regional Gross Valued Added Using Shift-share Analysis. Econ Lab Market Rev 4 p. 64. 
21. Pomianek, I. (2016). Charakterystyka potencjalu gospodarczego oraz przestrzennych zroznicowan rozwojowych gmin wiejskich wojewodztwa lubelskiego (Characteristics of Economic Potential and Spatial Development Differentiation of Rural Communes in Lubelskie Voivodship). Acta Universitatis Lodziensis. Folia Oeconomica 2016, Vol. 4, nr 323 pp. 81-102.

22. Rakowska, J. (2016). Samorzady gmin jako beneficjenci polityki spojnosci UE w latach 2007-2013 (2015). (Local Self-goverments as Beneficiaries of the EU Cohesion Policy in the Period 2007-2013 (2015), Wydawnictwo SGGW, Warszawa, p. 21.

23. Sobczak, E. (2015). Poziom specjalizacji w sektorach intensywnosci technologicznej a efekty zmian liczby pracujacych w wojewodztwach Polski (Specialization in Sectors of Technical Advancement vs. Effects of Workforce Number Changes in Poland's Voivodships). Research Papers Of Wroclaw University Of Economics nr 384, pp. 271-279.

24.Stimson, R.J., Stough, R.R., Roberts, B.H. (2006). Regional Economic Development: Analysis and Planning Strategy. Springer Science \& Business Media, p. 115.

25. Ward N., Brown, D.L. (2009). Placing the Rural in Regional Development. Regional Studies Volume 43, Issue 10.

26.Zemkova, K., Bartova, L. (2013). Regional Economy and Employment in Slovak Republic. Rural Development 2013, pp. 657-662. 